Available online at https://jurnal.stmikroyal.ac.id/index.php/jurdimas

\title{
PELATIHAN KETERAMPILAN MENJAHIT MASKER KAIN DALAM MEMANFAATKAN PELUANG BISNIS ERA PANDEMI COVID-19
}

\author{
Emilda $^{1}$, Try Wulandari ${ }^{1}$, Shafiera Lazuarni ${ }^{1}$ \\ ${ }^{1}$ Program Studi Manajemen, Universitas Indo Global Mandiri Palembang \\ email: emilda@uigm.ac.id
}

\begin{abstract}
Nowadays, medical mask is difficult to find in several pharmacies in Palembang. This situation could be a promising business opportunity during the Covid-19 epidemic. The target partners in this activity are residents of Gang Sei Saling, Siring Agung Sub-district, Ilir Barat 1 District, Palembang. This PkM activity aims to provide cloth mask sewing skills to take advantage of business opportunities during the Covid-19 pandemic. The method used in this activity is the training method. The sewing training activities consist of two types of activities, namely the presentation of sewing theory and practical training on sewing cloth masks. The presentation is going to explain about sewing theory, sewing concepts, tools and equipment needed in sewing, types and selection of fabrics. Meanwhile, training for sewing cloth masks, undoing the practice of operating a sewing machine, making cloth mask patterns, cutting patterns, sewing cloth masks, and finishing. In this PkM activity, participants not only provided skills in sewing cloth masks, but also at the finishing step such as folding and packaging.
\end{abstract}

Keywords: training; sewing; cloth masks

\begin{abstract}
Abstrak: Dengan adanya kelangkaan masker medis yang mulai sulit ditemukan di apotek Palembang, hal ini menjadi peluang bisnis di masa pendemi Covid - 19. Target mitra dalam kegiatan ini adalah Warga Gang Sei Saling, kelurahan Siring Agung, kecamatan Ilir Barat 1, Palembang. Kegiatan PkM ini bertujuan memberikan keterampilan menjahit masker kain untuk memanfaatkan peluang bisnis pada saat pandemi Covid - 19. Metode yang digunakan dalam kegiatan ini adalah metode pelatihan. Kegiatan pelaksanaan pelatihan menjahit ini terdiri dari dua jenis kegiatan yaitu pemaparan teori menjahit dan pelatihan praktek menjahit masker kain. Pemaparan teori menjahit terdiri konsep menjahit, peralatan dan perlengkapan yang dibutuhkan dalam menjahit, dan jenis dan pemilihan kain. Sedangkan kegiatan pelatihan praktek menjahit masker kain terdiri dari praktek mengoperasikan mesin jahit,membuat pola masker kain, menggunting pola, menjahit masker kain, dan finishing. Dalam kegiatan PkM ini, peserta tidak hanya diberikan keterampilan menjahit masker kain, tetapi juga hingga tahap finishing seperti melipat dan mengemas masker kain.
\end{abstract}

Kata kunci: masker kain; menjahit; pelatihan 
Available online at https://jurnal.stmikroyal.ac.id/index.php/jurdimas

\section{PENDAHULUAN}

Virus Covid-19 pertama kali mencuat di daerah Wuhan, China pada akhir Desember 2019 lalu. Namun, virus Covid-19 baru diketahui sudah menyebar di Indonesia ketika ada dua warga Indonesia yang terdeteksi positif virus Covid19 pada awal bulan maret 2020 karena tertular dari seorang warga negara jepang. Penyebaran virus Covid-19 sangat cepat. Pada bulan April, Covid-19 sudah menyebar ke berbagai provinsi di Indonesia. Di kota Palembang sendiri, pasca ada satu orang warga sumsel yang terkonfirmasi positif covid-19 pada tanggal 24 Maret 2020, kepanikan akan penularan Covid-19 makin memuncak. Masyarakat mulai menyikapi secara serius bahaya virus Covid-19 seiring semakin cepatnya penyebaran virus ini dan peningkatan jumlah orang yang terdeteksi positif covid-19 yang tinggi pada tiap harinya.

Kepanikan akan penularan covid19 terlihat dari sikap aware masyarakat terhadap pentingnya menggunakan masker yang ditunjukkan dengan permintaan masker yang tinggi. Permintaan yang tinggi terhadap masker yang tidak diikuti dengan jumlah masker yang tersedia di berbagai apotek dan supermarket membuat keberadaan masker menjadi langkah. Meskipun ada masker yang dijual di apotek, harga masker melambung tinggi bahkan harganya menjadi dua kali lipat bahkan lebih dari harga normal. Dengan adanya kelangkaan masker medis yang mulai sulit ditemukan di apotek Palembang, hal ini menjadi peluang bisnis di masa pendemi Covid 19. Tak heran jika penjual masker kain non medis mulai bermunculan sebagai solusi alternatif untuk memenuhi kebutuhan masker medis yang langka dalam upaya mencegah penularan Covid-19.
Masker kain non-medis memiliki kelebihan yaitu bisa digunakan sebagai pemakaian berulang karena bisa dicuci sehingga lebih efisien jika dibandingkan masker medis yang hanya bisa digunakan untuk sekali pakai. Selain itu, masker kain memiliki variasi dan bahan kain yang beragam sehingga pengguna masker bisa memiliki banyak pilihan untuk memilih masker kain non medis sesuai keinginan dan kebutuhan.

Namun sayangnya, peluang bisnis ini belum bisa dimanfaatkan oleh semua orang karena beberapa kendala, salah satunya adalah keterampilan. Keterampilan khusus merupakan salah satu faktor yang yang akan mempengaruhi kondisi ekonomi masyarakat (Sucipto \& Sutarto, 2015). Pelatihan membuat masker kain merupakan solusi alternatif dalam mengatasi kelangkaan masker di pasaran (Armiani,Fajri, Sukri \& Pidiawati, 2020).

Pelatihan merupakan bagian dari pendidikan nonformal untuk meningkatkan keterampilan sehingga dapat membantu meningkatkan perekonomian keluarga (Sucipto \& Sutarto, 2015). Dampak pandemi covid-19 paling dirasakan masyarakat yang memiliki penghasilan rendah dan tidak tetap. Warga gang Sei Saling di Palembang secara umum memiliki penghasilan rendah dan tidak tetap karena mayoritas kepala rumah tangga di gang Sei Saling adalah buruh bangunan harian.

Adapun permasalahan yang dihadapi mitra saat ini :

\section{Penghasilan Rendah Tidak Tetap}

Mayoritas pekerjaan warga di gang Sei Saling, kelurahan Siring Agung, kecamatan Ilir Barat 1, Palembang adalah buruh bangunan harian yang dibayar $\mathrm{Rp}$ $100.000-150.000$ per hari. Pekerjaan sebagai buruh bangunan termasuk pekerjaan yang tidak tetap karena berdasarkan 
Available online at https://jurnal.stmikroyal.ac.id/index.php/jurdimas

ada atau tidaknya tawaran lanjutan sebagai buruh bangunan untuk proyek berikutnya. Kondisi pandemi seperti ini membuat kondisi perekonomian semakin sulit. Pembatasan aktivitas masyarakat yang dilakukan pemerintah berdampak pada kondisi ekonomi masyarakat. Permintaan pembangunan rumah, ruko, dan bangunan lainnya menurun selama pandemi Covid-19.

\section{Kurang Maksimalnya Peran Wanita}

Mayoritas wanita di gang Sei Saling hanya sebagai Ibu Rumah Tangga sehingga kondisi ekonomi keluarga sangat bergantung pada penghasilan suami. Dengan adanya pandemi Covid - 19 membuat kondisi ekonomi mereka semakin sulit karena selama pandemi ini tawaran pekerjaan sebagai buruh bangunan mulai sepi. Dengan kondisi ekonomi yang semakin sulit, perempuan harus memaksimalkan peran yang tidak hanya sebagai isteri dan ibu bagi suami dan anak - anaknya, tetapi perempuan juga perlu mandiri untuk mendukung keuangan keluarga.

\section{Kurangnya Keterampilan}

Wanita agar dapat mendukung keuangan keluarga diperlukan keterampilan. Wanita di gang Sei Saling sebagian besar tidak memiliki pendidikan tinggi, sehingga hal ini membuat pilihan hidup terbatas. Keterampilan adalah hal yang sangat penting dalam menjalankan usaha. Untuk mendapatkan keterampilan bisa melalui mengikuti pelatihan atau kursus. Namun, biaya kursus keterampilan menjahit yang cukup mahal menjadi kendala. Tujuan PkM ini adalah melakukan pemberdayaan kepada masyarakat melalui pelatihan keterampilan menjahit masker kain dalam upaya memanfaatkan peluang bisnis pada kondisi pandemi Covid-19.

\section{METODE}

Metode yang digunakan dalam kegiatan PkM ini menggunakan metode pelatihan. Pelatihan adalah kegiatan yang melibatkan kegiatan yang disertai dengan demonstrasi dan pengoperasian sistem atau peralatan (Morelli, 2015). Sedangkan prosedur tahapan yang akan dilakukan untuk mendukung keberhasilan kegiatan adalah persiapan, pelaksanaan kegiatan dan evaluasi pelaksanaan (Aisyah \& Kurniawati, 2019)

Pelaksanaan pelatihan menjahit ini dilakukan di salah satu rumah warga di gang Sei Saling, kelurahan Siring Agung, kecamatan Ilir Barat 1, Palembang untuk memudahkan kegiatan PkM agar berdekatan dengan lokasi mitra. Mengingat kegiatan PkM ini dilaksanakan pada saat pandemi covid - 19, sehingga kegiatan PkM ini dibagi menjadi 2 kelompok dimana setiap kelompok dibatasi maksimal 5 orang untuk menghindari perkumpulan orang terlalu banyak (social distancing).

Tahapan kegiatan PkM ini terdiri dari persiapan tim PkM, observasi lokasi mitra, menyiapkan hal yg dibutuhkan untuk pelaksanaan kegiatan PkM, Pelaksanaan, Evaluasi dan membuat laporan kegiatan PkM. Tahap persiapan tim menentukan siapa yang menjadi anggota tim PkM dan pembagian tugas untuk setiap orang dalam Tim PkM ini, serta melakukan penyusunan jadwal untuk observasi dan pelaksanaan kegiatan PkM.

Selanjutnya melakukan peninjauan lokasi untuk melihat situasi dan permasalahan yang ada di gang Sei Saling, kelurahan Siring Agung, kecamatan Ilir Barat 1, Palembang dan melakukan evaluasi terhadap kegiatan pelaksanaan apakah hasil dari pelaksanaan kegiatan sudah sesuai dengan tujuan yang diharapkan. Tujuan dari memberikan 
Available online at https://jurnal.stmikroyal.ac.id/index.php/jurdimas

pelatihan ini adalah memberikan pelatihan menjahit masker kain agar peserta dapat memanfaatkan peluang bisnis di masa pandemi Covid - 19 dengan membuat dan menjual masker kain.

\section{PEMBAHASAN}

\section{Persiapan Pelatihan Menjahit}

Sebelum melaksanakan kegiatan pelatihan menjahit, Tim PkM mempersiapan perlengkapan dan peralatan yang dibutuhkan dalam menjahit. Pada gambar 1, merupakan gambar saat tim PkM membeli perlengkapan yang dibutuhkan dalam menjahit. Selain membeli kain, Tim PkM juga membeli perlengkapan dan peralatan yang dibutuhkan dalam menjahit lainnya seperti benang, gunting, karet, mistar jahit, meteran, jarum, dan kapur jahit.

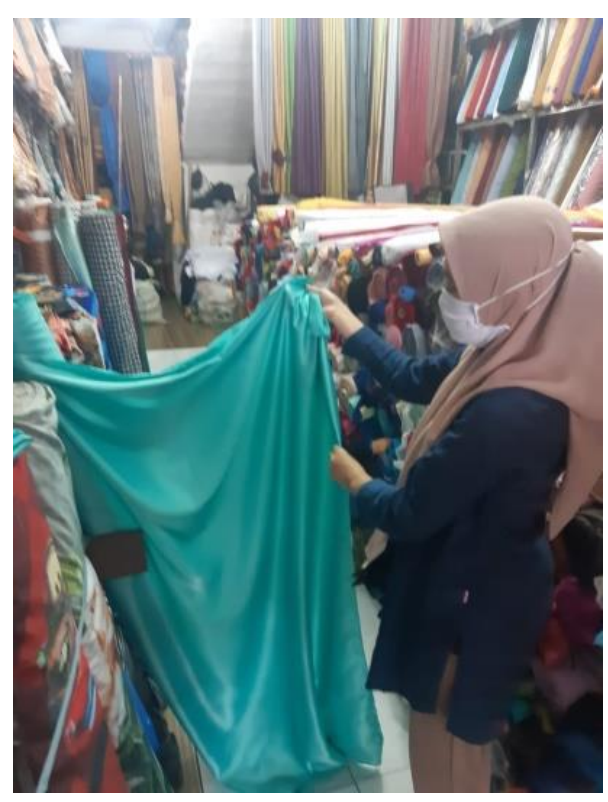

Gambar 1. Tim PkM sedang Membeli Bahan Kain di Pasar 16 Plembang

Namun, untuk peralatan mesin jahit tidak disiapkan dari Tim PkM karena mesin jahit sudah ada. Mesin jahit yang digunakan dalam pelatihan menjahit adalah milik salah satu warga gang Sei Saling yang tidak terpakai sehingga bisa dimanfaatkan dalam kegiatan pelatihan menjahit ini. Pada gambar 2, merupakan gambar perlengkapan dan peralatan yang dibutuhkan dalam menjahit.

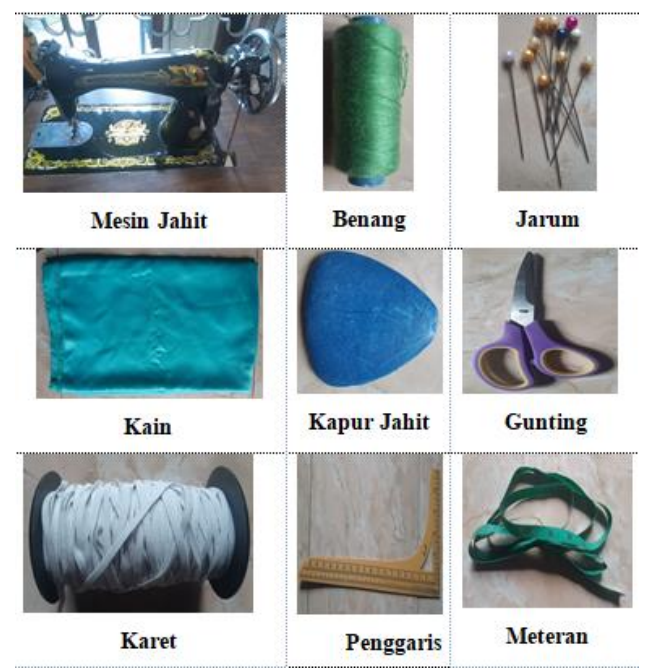

Gambar 2. Peralatan dan Perlengkapan Kegiatan Pelatihan Menjahit

\section{Pelaksanaan Pelatihan Menjahit}

Pelatihan menjahit adalah pendidikan nonformal yang menggunakan metode pelatihan yang berbasis kompetensi yang memberikan pengetahuan dan keterampilan mengenai proses menjahit. Pelaksanaan pelatihan menjahit dalam kegiatan PkM ini dilakukan di salah satu rumah warga di gang Sei Saling, kelurahan Siring Agung, kecamatan Ilir Barat 1, Palembang. Mengingat kegiatan PkM ini dilaksanakan pada saat pandemi Covid - 19, sehingga kegiatan PkM ini dibagi menjadi 2 kelompok dimana setiap kelompok dibatasi maksimal 5 orang untuk menghindari perkumpulan orang terlalu banyak (social distancing).

Dalam pelaksanaan pelatihan dapat dilakukan dengan metode kombinasi teori dan aplikasi (Niati \& Afifah, 2020). Kegiatan PkM ini dibagi menjadi 
Available online at https://jurnal.stmikroyal.ac.id/index.php/jurdimas

2 kegiatan yaitu pertama, penyampaian teori menjahit dan kedua, pelaksanaan praktek menjahit masker kain.

\section{Pemaparan Teori}

Sebelum memberikan pelatihan menjahit masker kain, peserta perlu mendapatkan pengetahuan mengenai teori menjahit. Jadwal pelaksanaan kegiatan pemaparan teori menjahit dijelaskan pada table 1 sebagai berikut

Tabel 1. Jadwal Kegiatan Pemaparan Teori

\begin{tabular}{ll}
\hline $\begin{array}{l}\text { Tema } \\
\text { Kegiatan }\end{array}$ & $\begin{array}{l}\text { Pemaparan Teori } \\
\text { Menjahit }\end{array}$ \\
\hline Hari/ Tanggal & $\begin{array}{l}\text { Sabtu dan Minggu, 25 } \\
\text { dan 26 Juli 2020 }\end{array}$ \\
\hline Tempat & $\begin{array}{l}\text { Gang Sei Saling, Ke- } \\
\text { lurahan Siring Agung, } \\
\text { Kecamatan Ilir Barat } \\
\text { 1, palembang }\end{array}$ \\
& $\begin{array}{l}\text { 1. } \begin{array}{l}\text { Teori menjahit } \\
\text { peralatan dan per- } \\
\text { lengkapan yang } \\
\text { dibutuhkan dalam } \\
\text { menjahit } \\
\text { jenis dan pemilihan } \\
\text { kain }\end{array} \\
\text { Materi }\end{array}$ \\
$\begin{array}{l}\text { Teknik pem- } \\
\text { aparan }\end{array}$ & Ceramah \\
\hline
\end{tabular}

Kegiatan ini bekerja sama dengan pihak yang memiliki kompetensi di bidangnya yaitu orang yang bisa menjahit. Pemaparan teori dijelaskan oleh Ibu Tuminah sebagai instruktur (gambar 3). Masyarakat diberikan pemaparan jenis/bahan kain dan alat-alat yang dibutuhkan untuk menjahit masker kain (gambar 4).

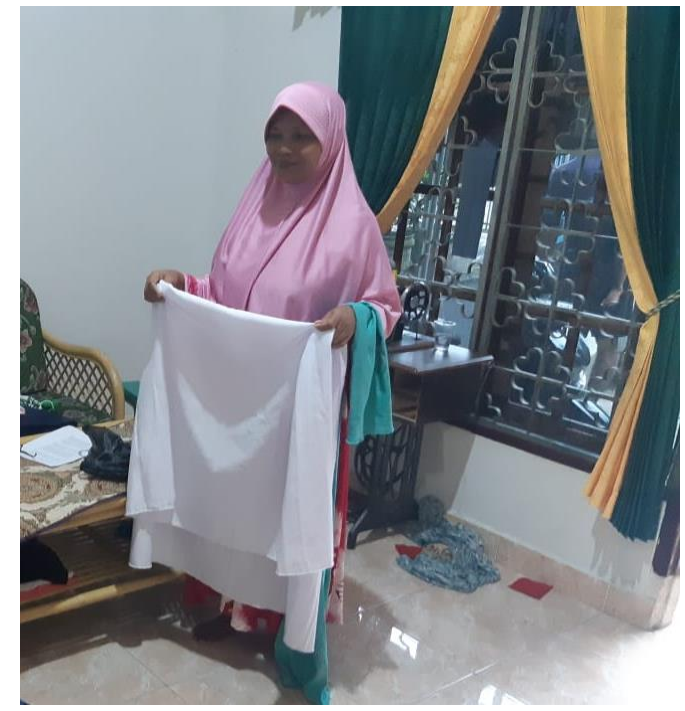

Gambar 3. Penyampaian Materi tentang Kain

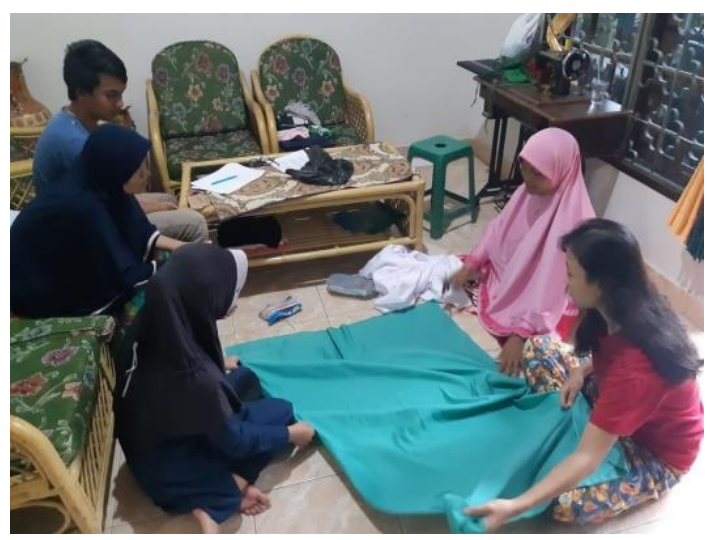

Gambar 4. Pemaparan Materi tentang Perlengkapan dan Peralatan Menjahit

\section{Praktek Menjahit.}

Kegiatan praktek menjahit dilaksanakan dirumah salah satu warga di gang Sei Saling yang memiliki mesin jahit yang tidak terpakai. Lama kegiatan praktek menjahit ini berlangsung selama 1 minggu. Jadwal kegiatan pelatihan menjahit masker kain dapat dilihat pada tabel 2. 
Available online at https://jurnal.stmikroyal.ac.id/index.php/jurdimas

Tabel 2. Jadwal Pelaksanaan Pelatihan Menjahit

\begin{tabular}{|c|c|}
\hline $\begin{array}{l}\text { Tema } \\
\text { Kegiatan }\end{array}$ & $\begin{array}{l}\text { Pelatihan Praktek Menjahit } \\
\text { Masker Kain }\end{array}$ \\
\hline Tempat & $\begin{array}{l}\text { Gang Sei Saling, Kelurahan } \\
\text { Siring Agung, Kecamatan } \\
\text { Ilir Barat 1, palembang. }\end{array}$ \\
\hline $\begin{array}{l}\text { Jadwal } \\
\text { Pelatihan }\end{array}$ & $\begin{array}{l}\text { Satu kali per minggu setiap } \\
\text { hari minggu ( } 2 \mathrm{Agt}-6 \mathrm{Sept} \\
\text { 2020) }\end{array}$ \\
\hline Kegiatan & $\begin{array}{l}\text { Praktek mengoperasikan } \\
\text { mesin jahit } \\
\text { Membuat pola masker kain } \\
\text { Menggunting pola } \\
\text { Menjahit masker kain } \\
\text { Finishing }\end{array}$ \\
\hline Metode & Pelatihan \\
\hline
\end{tabular}

Kegiatan pelatihan menjahit masker kain dimulai dari beberapa tahapan yaitu pertama, praktek mengoperasikan mesin jahit. Kedua, membuat pola. Ketiga, menggunting pola. Keempat, menjahit pola, dan kelima, penyelesaian (finishing) seperti melipat dan mengemas masker kain. Berikut uraian kegiatan dalam pelatihan menjahit.

\section{Pertama, Praktek Mengoperasikan Mesin Jahit}

Mesin jahit yang digunakan dalam pelatihan keterampilan menjahit ini adalah mesin jahit yang manual, bukan portable. Kelebihan mesin jahit manual jika dibandingkan dengan mesin jahit portable adalah mesin jahit manual menggunakan pedal sehingga bisa digunakan jika listrik padam dan kerangka mesin jahit manual terbuat dari besi sehingga lebih kuat dan awet jika dirawat dengan baik. Dalam belajar menjahit yang diperlukan tidak hanya pengetahuan dan pemahaman menjahit, tetapi juga perlu bisa mengoperasikan mesin jahit. Karena dalam kegiatan pelatihan ini meng-gunakan mesin jahit manual, sehingga tahapan yang dipelajari dalam mengoperasikan mesin jahit diperuntukkan penggunaan mesin jahit manual.

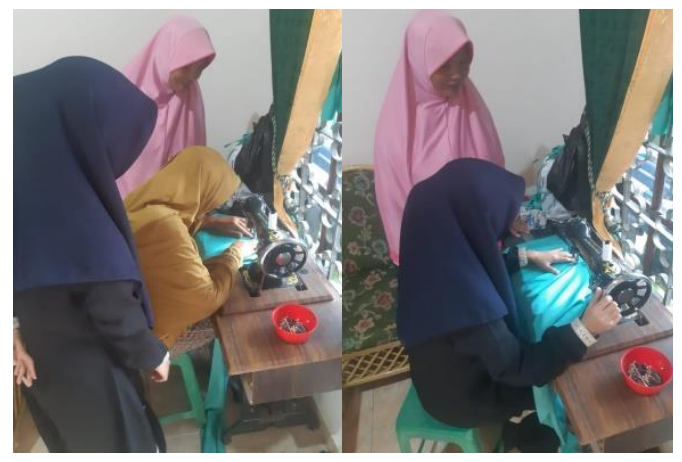

Gambar 5. Peserta Belajar Mengoperasikan Mesin Jahit

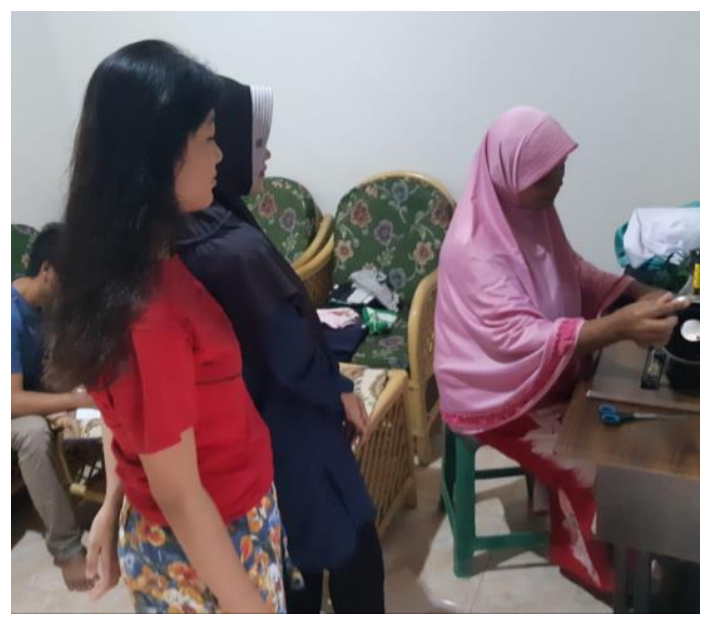

Gambar 6. Instruktur Mengajar Mengoperasikan Mesin Jahit

Hal - hal yang dipelajari dari pelatihan mengoperasikan mesin jahit manual adalah pertama, cara mengisi benang pada spul. Masukkan spul di penggulung benang, pasangkan benang di spul yang terdapat di penggulung benang, kemudian jalankan mesin jahit untuk mengisi benang pada spul hingga penuh. Kedua, mengatur tegangan mesin jahit. Dalam mengatur tegangan benang mesin 
Available online at https://jurnal.stmikroyal.ac.id/index.php/jurdimas

jahit itu terletak di bagian sebelah kiri mesin jahit, makin besar nomornya, maka makin kencang. Ketiga, mengatur jarak setikan mesin jahit. Keempat, memasang jarum. Kelima, memasang spul pada skoci. Keenam, memasang benang pada jarum. Ketujuh, menjalankan mesin jahit.

\section{Kedua, Membuat Pola Masker Kain.}

Desain pola membutuhkan kehatihatian dan konsentrasi yang tinggi karena dalam membuat pola melibatkan proses penjumlahan, pengurangan, pembagian dan perkalian (Syafri, 2007). Dalam membuat pola yang diperlukan adalah kain, penggaris, kapur untuk membuat pola. Ukuran pola masker kain yang akan dibuat dalam pelatihan ini adalah $20 \times 20$ CM Pola masker kain yang dibuat dalam pelatihan ini terdiri dari beberapa kategori yaitu membuat pola masker kain tali, headloop dan earloop. Ukuran masker pada dasarnya sama, perbedaannya terletak pada headloop dan earloop menggunakan karet sedangkan masker kain tali diperlukan pola tambahan yang digunakan untuk membuat tali masker.

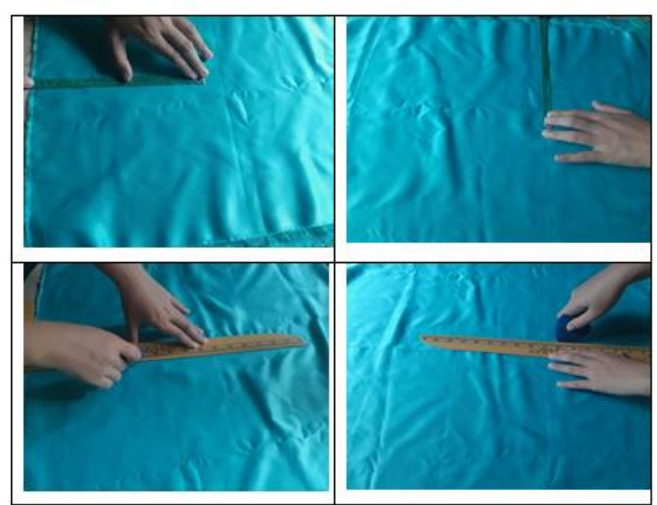

Gambar 7. Membuat Pola

Pada gambar 7, Peserta belajar membuat pola dengan langsung menggambar pola diatas kain dengan menggunakan kapur dan mistar jahit. Tetapi, pada dasarnya dalam konsep menjahit secara umum, mengambar pola biasanya di kertas pola, bukan diatas kain secara langsung.

\section{Ketiga, Menggunting Pola.}

Setelah membuat pola masker, tahap selanjutnya adalah menggunting pola yang sudah dibuat. Dalam menggunting pola pada kain, ada teknik yang digunakan agar kain yang digunting rapih dari sisi depan dan belakang. Dalam menggunting pola pada kain, kain jangan diangkat. Kain harus diletakkan di lantai atau meja dengan tangan menekan dasar kain untuk menahan dasar kain agar tidak terangkat dan tangan yang lain menggunting. Berikut gambar kegiatan peserta menggunting pola masker.

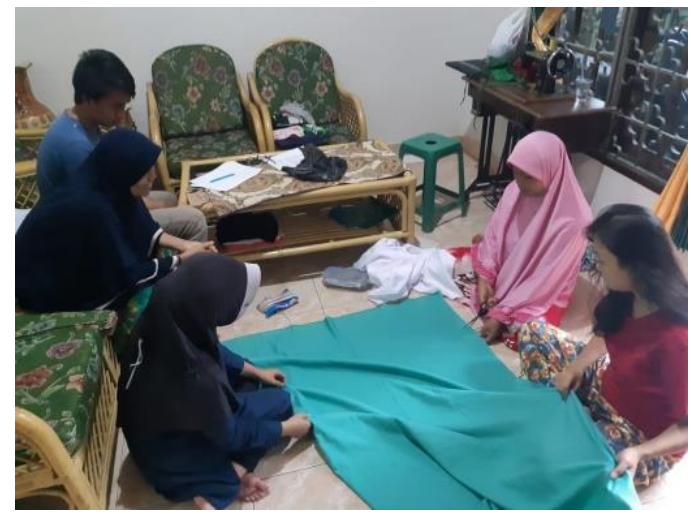

Gambar 8. Instruktur menjelaskan cara menggunting pola

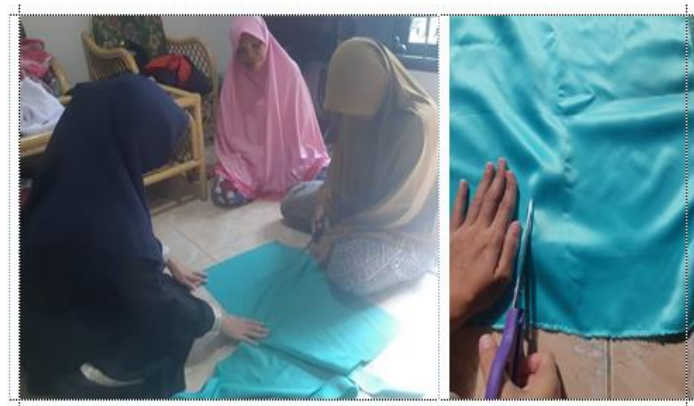

Gambar 9. Peserta Praktek Menggunting Pola 
Available online at https://jurnal.stmikroyal.ac.id/index.php/jurdimas

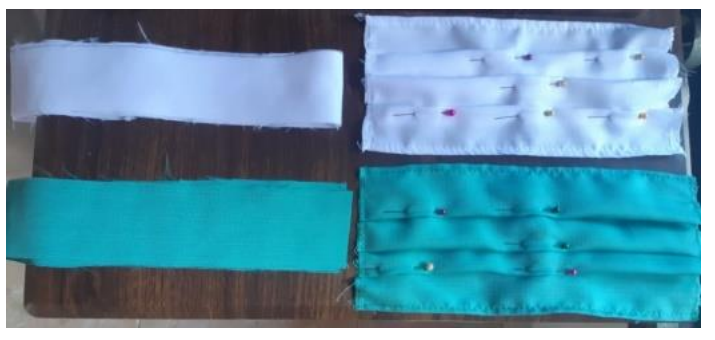

Gambar 10. Hasil pola yang sudah digunting

\section{Keempat, Menjahit Masker Kain}

Keterampilan menjahit adalah kemampuan untuk mengeluarkan kreatifitas dalam upaya mengerjakan proses menyambung kain, bulu, kulit binatang, maupun bahan-bahan lain yang bisa dilewati jarum jahit dan benang (Sukmawati, 2018). Menjahit dapat dilakukan dengan tangan memakai jarum tangan atau dengan mesin jahit (Ramadani \& Novrita, 2019).

Jumlah mesin jahit yang ada hanya terdapat 1 unit sehingga peserta praktek menjahit masker kain harus bergantian. Berikut gambar beberapa peserta yang sedang praktek menjahit masker kain yang berhasil didokumentasikan.

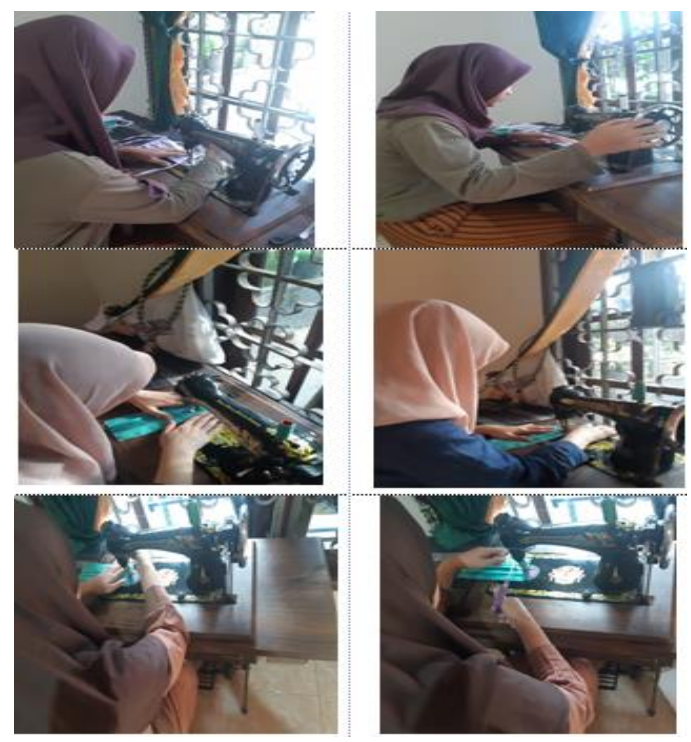

Gambar 11. Peserta sedang Menjahit Pola Masker Kain
Hasil dari pelatihan menjahit berupa peserta memiliki keterampilan menjahit khususnya bisa membuat masker kain yang bertali, headloop, dan earloop. Berikut gambar hasil pelatihan menjahit masker kain selama 1 bulan kepada peserta di Gang Sei Saling, Kelurahan Siring Agung, Kecamatan Ilir Barat 1, Palembang.

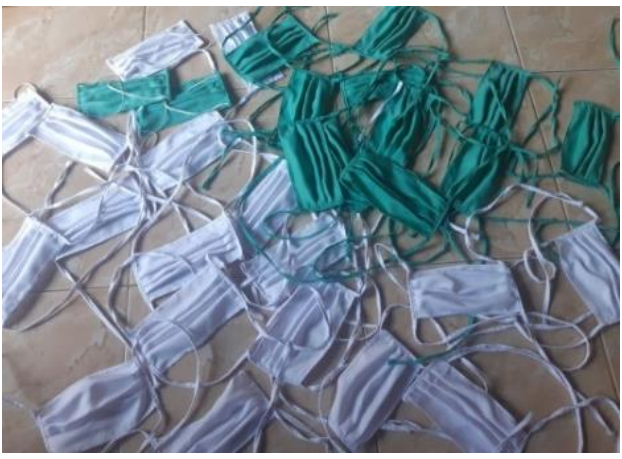

Gambar 12. Hasil Pelatihan Menjahit Masker Kain

\section{Kelima, Penyelesaian (Finishing)}

Dalam kegiatan PkM ini, peserta tidak hanya diberikan mengenai keterampilan menjahit masker kain, tetapi juga diajarkan hingga tahap finishing. Finishing adalah kegiatan penyelesaian akhir yang meliputi pemeriksaan (inspection), pembersihan (triming), penyetrikaan (pressing) serta melipat dan mengemas (Astuti \& Luayyi, 2019)

Pemeriksaan (inspection) merupakan kegiatan yang menentukan kualitas dari hasil jahitan. Setelah dilakukan pemeriksaan ini dilakukan pemisahan yang hasilnya baik dan yang tidak baik. Langkah selanjutnya adalah pembersihan (trimming yaitu sisa - sisa benang dibuang. Pakaian yang sudah dibersihkan dilanjutkan ke bagian penyetrikaan (pressing). Setelah disetrika, masker kain dilipat dengan rapih dan kemudian tahap terakhir adalah mengemas. Pada gambar 13 merupakan cara mengemas jenis 
Available online at https://jurnal.stmikroyal.ac.id/index.php/jurdimas

masker kain yang bertali, karena masker jenis lainnya yaitu headloop dan earloop sanggat mudah dikemas yang hanya dimasukkan dalam plastik saja agar rapih.

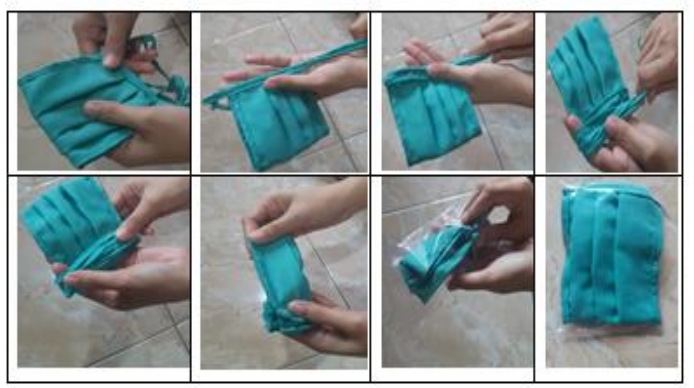

Gambar 13. Proses Pengemasan Masker Kain

\section{Evaluasi Kegiatan}

Tahap evaluasi merupakan proses yang berfungsi untuk mengetahui dan mengukur hasil dari pembelajaran yang telah dilaksanakan (Wahyuni \& Sutarto, 2018). Setelah pelaksanaan kegiatan selesai dilakukan, maka perlu dilakukan evaluasi untuk menilai keberhasilan kegiatan pelatihan menjahit masker kain. Pada tabel 3 merupakan hasil evaluasi kegiatan pelatihan menjahit masker kain.

Tabel 3. Evaluasi Kegiatan Pelatihan

\begin{tabular}{ll}
\hline \multicolumn{2}{c}{ Evaluasi } \\
\hline $\begin{array}{l}\text { Kriteria } \\
\text { keberhasilan }\end{array}$ & $\begin{array}{l}\text { Hasil Evalusi Akhir } \\
\text { Kegiatan }\end{array}$ \\
\hline $\begin{array}{l}\text { Peserta mam- } \\
\text { pu membuat }\end{array}$ & Semua peserta dalam \\
masker kain & kegiatan ini bisa mem- \\
& mun, kemampuan peser- \\
& ta untuk bisa menjahit \\
& berbeda - beda. Namun \\
& secara rata - rata, mulai \\
& bisa menjahit membu- \\
& tuhkan waktu 3 hingga 4 \\
kali pertemuan.
\end{tabular}

\section{SIMPULAN}

Dalam pelaksanaan kegiatan $\mathrm{PkM}$ diperuntukkan bagi warga di gang Sei Saling, kelurahan Siring Agung, Palembang yang berpenghasilan rendah dan tidak tetap yang membutuhkan pelatihan menjahit masker kain untuk memanfaatkan peluang bisnis pada masa pandemi Covid-19, memperoleh hasil yang baik, dimana warga khususnya ibu kelurahan Siring Agung, Palembang mendapatkan pengetahuan dan pemahaman mengenai menjahit, mendapatkan keterampilan menjahit masker kain hingga cara mengemas masker untuk dijual. Dapat disimpulkan ibu warga gang Sei Saling, kelurahan Siring Agung, Palembang memiliki penghasilan sendiri dengan pengetahuan dan keterampilan yang telah diperoleh setelah pelatihan, dan dapat membantu meningkatkan pendapatan keluarga.

\section{DAFTAR PUSTAKA}

Aisyah, S., \& Kurniawati. (2019). PKM keterampilan menjahit pada remaja putri di Desa Bonto Jai Kecamatan Bissapu Kabupaten Bantaeng. Prosiding Seminar Nasional, 1-4.

Armiani, S., Fajri, S. R., Sukri, A., \& Pidiawati, B. Y. (2020). Pelatihan Pembuatan Masker Sebagai Upaya Antisipasi Penyebaran Covid-19 di Desa Anyar Kabupaten Lombok Utara. Jurnal Pengabdian UNDIKMA, 1(1), 2227.

https://doi.org/10.33394/jpu.v1i1. 2550

Astuti, I. Y., \& Luayyi, S. (2019). Pelatihan Kewirausahaan Keterampilan Menjahit Bagi 
Available online at https://jurnal.stmikroyal.ac.id/index.php/jurdimas

Masyarakat Desa Damarwulan Kecamatan Kepung Kabupaten Kediri. Cendekia: Jurnal Pengabdian Masyarakat, 1(1), 1. https://doi.org/10.32503/cendekia. v1i1.408

Morelli, N. (2015). Challenges in designing and scaling up community services. The Design Journal, 18(2), 269-290. https://doi.org/doi.org/10.2752/17 5630615X14212498964394

Niati, B., \& Afifah, N. (2020). PKMTata Busana di Desa Suka Damai Kecamatan Ujungbatu Rokan Hulu. Dinamisia, 4, 161-168.

Ramadani, P., \& Novrita, S. Z. (2019). Peningkatan Hasil Belajar Keterampilan Menjahit Rok Melalui Media Mock Up Di Kelas Tata Busana Siswa Slb Negeri 2 Padang. Gorga: Jurnal Seni Rupa, 8(1), 203. https://doi.org/10.24114/gr.v8i1.1 3170

Sucipto, N. R., \& Sutarto, J. (2015). Pemberdayaan Masyarakat Miskin Untuk Meningkatkan Kecakapan Hidup Melalui Kursus
Menjahit Di Lkp Elisa Tegal. Journal of Nonformal Education and Community Empowerment, 4(2), 135-142.

Sukmawati, T. (2018). Upaya LKP Lucky Dalam Meningkatkan Keterampilan Melalui Program Kursus Menjahit (Studi Kualitatif bagi kalangan perempuan di LKP Lucky desa Tanimulya kecamatan Ngamprah Kab. Bandung barat). Comm-Edu, 1(20), 30-37. http://download.garuda.ristekdikti .go.id/article.php?article $=816438$ \&val=13334\&title=Upaya LKP LUCKY dalam Meningkatkan Keterampilan Melalui Program Kursus Menjahit

Syafri, H. (2007). Modul Konstruksi Pola Busana Wanita. Universitas Negeri Padang.

Wahyuni, S., \& Sutarto, J. (2018). Pembelajaran Kursus Menjahit di Lembaga Kursus dan Pelatihan Gassebo Kabupaten Kendal. Jurnal Pendidikan Dan Pemberdayaan Masyarakat, Vol 5. 